3. Hereta. I. (1978) Museum of Solomiya Krushelnitska: [drawing-way]. Lviv: Kameniar, p. 58. [in Ukrainian].

4. Derkach I. (1964) Popular vocalist. Lviv: Kameniar [in Ukrainian].

5. Dmitriieva L., Chernoivanenko N. (1989) Technique of musical education at school. Moscow, Russia, [in Russian].

6. Solomiia Krushelnytska (1978). Memoirs. U 2-kh ch. Ch.1: Spohady. Ukraina. Kyiv, p. 398. [in Ukrainian].

7. Rudenskyi E. (1991) Introduction to the psychology of festive communication. Kemerovo. ONUU [in Russian].

8. Solarska-Zachuta A. Teatr Lwowski w latach 1890-1918. Wprowadzenie. / Dzieje teatru polskiego. Teatr polski w latach 1890-1918: Zabor austriacki i pruski. - Warszawa: Panstwowe Wydawnictwo Naukowe, 1987. p. 199-228. [in Polish].

Стаття надійшла до редакції 13.12.2017

УДК 787.79(477)

DOI 10.31723/2524-0447-2018-26-255-266

Ірина Сергї̈вна Дружга

https://orcid.org/0000-0002-9741-2874,

здобувач кафедри історії української музики

та музичної фольклористики Національної музичної

академії імені П. І. Чайковського

minkyltyru0608@gmail.com

\title{
МЕТОДИЧНІ НАПРАЦЮВАННЯ БАНДУРИСТІВ ЗІНОВІЯ ШТОКАЛКА ТА ВАСИЛЯ ЕМЦЯ
}

Мета дослідження - проаналізувати методичні разробки, видані за кордоном: «Кобзарський підручник» Зіновія Штокалка і підручник «Кобза i кобзарі» - Василя Ємия. Методологія дослідження - застосовується аналіз робіт: «Кобзарський підручник» $i$ «Кобза і кобзарі». Наукова новизна полягає в більш комплексному дослідженні перших підручників гри на бандурі, виданих за кордоном. Їх значення для написання нових на основі вже існуючих досліджень бандуристів. Висновки. Таким чином, перші підручники Василя Смия та Зіновія Штокалка є основою для удосконалення наукової літератури. Написання нових шкіл гри на бандурі з освітленням нових професійних завдань. Удосконалення прийомів, способів звуковидобування на бандурі, удосконалення конструкції інструмента. Популяризація бандурного мистецтва через поєднання в репертуарі не тільки творів світової музичної класики, а також традиційного автентічного українського репертуару значно розширили виконавські риси інструменту. I тим самим не тільки створили сприятливі умови для виступів

() Дружга I. C., 2018 
з бандурою в світі, але і підготували грунт для розвитку традиційного українського народного мистецтва в нетрадиційних для нього умовах.

Ключові слова: бандура, підручник, Зіновій Штокалко, Василь Емець.

Druzhga Irina, postgraduate student of the History of Ukrainian music and folklore Faculty of National Music P. I. Tchaikovsky Academy of Ukraine

Methodical developments of bandurists Zinovy Shtokalka and Vasily Emets

The purpose of the study is to analyze the methodological developments issued abroad: «Kobzar textbook» by Zinovy Shtokalka and textbook «Kobza and Kobzari» Vasily Yemtsa Research methodology - the analysis of works: "Kobzar textbook» and «Kobza and Kobzari» are used. The scientific novelty consists in a more comprehensive study of the first textbooks on the game of bandura issued abroad. Their importance for writing new based on existing research bandura. Conclusions Thus, thanks to the first textbooks of Vasily Yemts and Zinovy Shtokalka, highlighted in the study by I. Druzhga, they are the basis for the improvement of scientific literature. Writing new schools of gambling with the coverage of new professional tasks. Improving the techniques, methods of sound extraction on the bandura, improving the design of the instrument. And the popularization of bandure art through the combination in the repertoire of not only the works of world classical music as well as the traditional aventtic, Ukrainian repertoire, significantly expanded the performance features of the instrument. And thus created not only favorable conditions for performances with bandura in the world, but also prepared the ground for the development of traditional Ukrainian folk art in unconventional conditions for it.

Keywords: bandura, textbook, Zinovy Shtokalko, Vasily Emets.

Дружга Ирина Сергеевна, соискатекаль кафедры истории украинской музыки и музыкальной фольклористики Национальной музыкальной академии имени П. И. Чайковского

Методические наработки бандуристов Зиновия Штокалко и Василия Емца

Цель исследования проанализировать методические разроботки, изданные за границей: «Кобзарский учебник» Зиновия Штокалко и учебник «Кобза и кобзари» Василия Емца. Методология исследования - применяется анализ работ: «Кобзарский учебник» и «Кобза и кобзари». Научная новизна заключается в более комплексном исследовании первых учебников игры на бандуре, изданных за рубежом. Их значение для написания новых на основе уже существующих исследований бандуристов. Выводы. Таким образом, первые учебники Василия Емия и Зиновия Штокалко являются основой для усовершенствования научной литературы. Написание новых школ игры на бандуре с освещением новых профессиональных задач. Совершенствование приемов, способов звукоизвлечения на бандуре, усовершенствование конструкции инструмента. А популяризация бандурного 
искусства благодаря сочетанию в репертуаре не только произведений мировой музыкальной классики, а также традиционного аутентичного, украинского репертуара, значительно расширили исполнительские черты инструмента. И тем самым не только создали благоприятные условия для выступлений с бандурой в мире, но и подготовили почву для развития традиционного украинского народного искусства в нетрадиционных для него условиях.

Ключевые слова: бандура, учебник, Зиновий Штокалко, Василий Емец.

Актуальність теми дослідження. У сучасному світі актуальним $є$ збереження та примноження національних традицій. Надбання українського народу - кобзарство та бандурництво $є$ національним мистецтвом. Особливо перші підручники та самовчителі гри на бандурі, видані за межами України. Їх цінність у тому, що можна простежити історію розвитку інструмента, репертуару та виконавців. Тому наше дослідження є актуальним та доцільним.

Проаналізувавши численні дослідження (В. Мішалова [6], В. Дутчак [1], Л. Майстренко [5] та ін.), ми бачимо, що питання аналізу перших методичних праць в діаспорі, на прикладі підручника Василя Ємця «Кобза та кобзарі» та «Кобзарського підручника» потребує уточнення та повнішого висвітлення, тому є актуальною темою сьогодення.

Мета статті - проаналізувати методичні надбання, видані за кордоном: «Кобзарський підручник» Зіновія Штокалка та підручника «Кобза та кобзарі» Василя Ємця.

Виклад основного матеріалу. Кобзарство - симбіоз культурної народної традиції та новотворення народного генія. I хоча в умовах еміграції бракує безпосереднього контакту з актуальною вітчизняною дійсністю, проте воно має всі дані для відтворення своїх традицій.

Наголошуємо, що цінність кобзарського мистецтва полягає переважно саме у його традиційності. Тому художня реконструкція старовинних кобзарських творів робить значну послугу не тільки сучасному кобзарству, але і всьому українському національному музично-поетичному мистецтву.

Зіновій Штокалко, один з найвідоміших бандуристів-кобзарів XX століття. Упродовж творчого життя він аранжував і обробив для бандури близько 400 народних пісень (козацьких, гайдамацьких, стрілецьких, повстанських, чумацьких, бурлацьких, парубоцьких, жартівливих), три билини, балади, канти, псалми, танцювальну музику, інтерпретував кобзарські танці тропак, козачок та ін. 
Він вперше систематизував відомі кобзарські строї, узагальнені із записів відомих етнографів та фольклористів, поділяючи їх на косий, кубанський, почаївський, жалібний; вводить термін «лебійських» строїв (від назви своєрідної кобзарської цехової мови - лебійської, в якій слово «лебій» означає «старець», «майстер-музикант»), застосовуючи цю назву для позначення звукорядів, що використовуються у старовинному репертуарі.

Зіновій Штокалко народився 25 травня 1920 р. в селі Кальне Козівського району на Тернопільщині в сім'ї о. Павла. Його гуманітарний нахил, а може й смерть трьох братів, сприяли тому, що він вибрав своїм фахом медицину. Та в міжвоєнній Польщі, у склад якої входила тоді Галичина, він не міг вивчати медицини і почав навчання в 1939 році, але його арештували німці й ув'язнили в Берліні. Медицину він закінчив після війни в Мюнхенському університеті, де 1951 р. захистив докторську дисертацію «Zur Biochemie der Karzinogenese» («До біохемії карциногенезу»).

3 молодих років Штокалко цікавився українським музичним фольклором. Він записував пісні, вивчав думи і сучасні пісні. Не відомо, коли Штокалко почав учитися грати на бандурі, але знаємо, що його першим учителем був Богдан Клевчуцький. Першу бандуру придбав батько в Києві 1918 р. для свого сина Івана і Зіновій успадкував iii після братової смерті. У 1939 р. Зіновій уже грає в тріо під керівництвом Юрія Сінгалевича, який мав поважний вплив на розвиток Штокалка як бандуриста (третім у тріо був Федір Якимець). Штокалко також грав із Семеном Ластовичем-Чулівським.

Це був не тільки добрий бандурист, але й прекрасний бандурник, що зробив для Штокалка інструмент, на якому той виконував майже весь свій репертуар, і який служить практичною основою його підручника.

Взявши за основу дослідження Миколи Лисенка та Гната Хоткевича та власний практичний доробок, 3. Штокалко написав у кінці 50 - на початку 60-х років XX ст. «Кобзарський підручник», де виклав свої тлумачення проблеми своєрідності автентичної бандури та пропозиції щодо необхідності іiі модернізації. Видання книги було здійснено в Україні у 1992 році під егідою Канадського інституту українських студій при Альбертському університеті.

Штокалко поділив свій «Підручник» на дві частини і кожна 3 них має черговість розділів. Перша - теоретичний «Вступ», а друга «Підручник», - практичний курс розвиткових вправ 3 поясненнями. 
У «Вступі» подано коротку історію інструмента; в загальних рисах розповідається про самовчитель гри, що стали першою упорядкованою та виданою фаховою бандурною літературою. Автор розглядає конструкцію інструмента, складові частини і характеризує три основні способи гри на бандурі.

В розділі «Про інструмент та його походження» підкреслено, що ні одна з гіпотез про походження бандури науково ще не обгрунтована. Він перераховує перші згадки про кобзу-бандуру, описує ії зовнішній вигляд та еволюційні зміни, велику увагу приділяє етимології назв інструмента, порушує питання про так званий «примітивізм» бандури; також в розділі є неодноразові посилання до матеріалів з теоретичних робіт Гната Хоткевича. Автор виступає проти удосконалення, а особливо універсалізації бандури, іiі хроматизації та виконання на ній творів світової класики, написаних для інших інструментів. Він переконаний, що бандура повинна не конкурувати з іншими інструментами, а зберегти свою традиційну національну сутність. В розділі містяться деякі помилкові твердження стосовно окремих історичних фактів; адже після Зіновія Штокалка дослідниками були знайдені нові відомості в з історії походження бандури [5].

В розділі «Кобзарські підручники» автор підкреслює, що його підручник, не є досконалим, як, наприклад, у піаністів та скрипалів їх школи. Він визначає, що підручник - це лише робочий метод, за допомогою якого можна засвоїти головні технічні можливості інструмента, залишаючи кожний крок для подальших удосконалень своїх знань.

Базуючись у практичній частині підручника на комбінованому способі гри, 3. Штокалко пропонує започаткувати курс науки гри 3 технічного розвитку правої руки, бандуриста як ведучої, на приструнках, використовуючи під час навчання вже засвоєні прийоми старої чернігівської та полтавської шкіл.

Досконало вивчивши простий виконавський матеріал названих кобзарських типів, на другому етапі опанування інструмента слід поступово переходити до вивчення і відшліфування більш складних прийомів, - вже харківського типу. Після розрізненого, але ретельного опрацювання прийомів зазначених шкіл треба використовувати у виконавській практиці поєднання кращих елементів трьох основних методик гри (харківської, полтавської та чернігівської).

Базуючись на засадах харківської школи гри, автор пояснює традиційні способи звуковидобування на бандурі обома руками, віднайшовши при цьому власний прийом удару по струнах, який, за сло- 
вами автора, «можна окреслити як щипаний удар». Характеризуючи основи гри кожною рукою, Зіновій Штокалко вказує на два основні положення рук, описані на початку XX століття Гнатом Хоткевичем у першому «Підручнику гри на бандурі». Перше - звичайне положення руки, що позначається великою літерою «З», друге - це прийом старої чернігівської школи: струна зачіпається нігтем. Він називається нігтьовим і позначається літерою «H».

3. Штокалко радить для гри на інструменті запровадити штучні нігті, що мають бути підігнані за довжиною та формою індивідуально, відповідно до форми пальця. Також радить старанно пильнувати нігті, користуючись пильником або особливим кліщиком, нігті мають мати гладкі береги. Ножиці не радить, бо їх трудніше застосовувати та вони роблять при окраїнні різні невидимі на перший погляд тріщинки, що пізніше можуть призвести до обламання нігтя, окрім цього ножиці залишать гострі кути, що також призводить до ламання нігтя.

У минулому кобзарі також застосовували для підсилення звуку спеціальне пристосування, це була дерев'яна кісточка, наткнута в кільце або наперсток, настромлений на другий палець правої руки аж до першого (кінцевого) суглоба пальця. На жаль, «кісточки» не можуть хоч частково дорівняти «живим» нігтям. У випадку надломлення нігтя треба вжити заходи для збереження можливості працездатності. Автор радить використовувати спеціальний «пластичний клей», що накладається на ніготь, а зверху прикладається шар тонкого паперу. Коли папір присохне, можна накласти шар нігтьового лаку, він зовсім замаскує «нігтьову протезу». Ця маска не може триматися довго, 2-4 дні і відпадає. Тому, залежно від потреби, автор радить за допомогою ацетону обережно зняти лак, щоб маска сама не відшарувалася і не зламала нігтя. Автор дає рекомендації з догляду за інструментом, після кожної гри його необхідно витирати сухим платком або краще змоченим в бензині [7, 22-51].

Друга частина «Кобзарського підручника» складається з розвиткових вправ, п'єс та пояснень стосовно їхнього виконання. Комплекс для зростання виконавської майстерності побудований 3. Штокалком за принципом поступового ускладнення технічного матеріалу. Автор пропонує спочатку розгляд вправ для кожного пальця правої руки, потім разом для двох, трьох, чотирьох. Наступний крок у процесі розвитку виконавської техніки - вправи на широкі інтервали: октави, акорди (трьохзвучні, чотирьохзвучні, ламані) та поєднання прийомів гри з попередніх завдань. Окремим параграфом подано 
вправи для лівої руки, що також скомпоновані на засадах їх поступового ускладнення. Також подає параграф вправ на обидві руки.

Загалом «Кобзарський підручник» 3. Штокалка містить нескладні, зручні й корисні вправи, а також ряд обробок українських народних пісень та авторських музичних творів багатьох відомих бандуристів (Г. Хоткевича, В. Щербини, Ю. Сінгалевича, К. Місевича, В. Ємця, М. Теліги, А. Горняткевича, В. Кухти та ін.).

Скомпонований 3. Штокалком репертуар для бандури досить об'ємний і охоплює всі жанри українського народного мелосу (історичні, козацькі, гайдамацькі, бурлацькі, чумацькі, кріпацькі, побутові, жартівливі та пісні про кохання). У 1996 році цей репертуарний збірник видатного бандуриста діаспори під назвою «Кобза» за редакцією професора А. Горняткевича, завдяки сприянню Канадського інституту українських студій і видавництва «Таксон» побачив світ, а в 1997 році був перевиданий в Україні.

На перший погляд може видатися, що пісенний матеріал, зібраний у цій праці, розпочатій понад шістдесят років тому, є застарілим або занадто простим для сучасного виконавця - доби стрімкого розвитку наукових і комп'ютерних технологій, через невисокий рівень технічних складностей. Адже традиційне кобзарство і народна музика спрямовані більше на емоції, думний характер виконання, ніж на сучасний професіоналізм.

Василь Смець [15(27).11.1890-6.01.1982, Лос-Анджелес, США] видатний бандурист-віртуоз, композитор, науковець, майстер бандур, громадський діяч. Народився в селі Шарівка Богодухівського повіту на Харківщині. Навчався в Охтирській гімназії. Вже будучи в п’ятому класі, у 1907 році залишає своє місце в гімназійному оркестрі, де грав на мандоліні, балалайці та гітарі, купує собі бандуру і вже не розлучається з нею все своє життя, вчиться сам и вчить інших. 6 грудня 1911 року вперше виступив зі своїм концертом в місті Охтирці. Публіка вітала його бурхливо, але за цей виступ бандуриста мало не вигнали з гімназії. Після закінчення гімназії В. Ємець поступив на природознавчий відділ фізико-математичного факультету Харківського університету. Тут він продовжує свої виступи, веде гурток бандуристів. Проте за участь у підготовці святкування 100 років від дня народження Т. Шевченка його було виключено з університету, і він мусив перевестися до університету в Москві.

Але і там продовжує концертувати. У 1914 році на всеслов’янському концерті разом з актором Малого імператорського театру Макси- 
мовичем репрезентує Україну. В Москві з'являється ще одна школа Ємця. Він виступає з бандурою у Великому імператорському театрі на концерті-ярмарку на користь жертв війни. Згодом в тому ж театрі виступає на концерті, присвяченому вшануванню оперного співака Івана Алчевського, і саме тоді видання «Русское слово» обдарувало його титулом віртуоза. По закінченню університету музикант короткий час вчителював в дівочій гімназії міста Сосниці на Чернігівщині. У 1917 році Василь Ємець переїхав до Києва і організував першу капелу бандуристів, дебют якої відбувся 3 листопада 1918 року у відомому київському театрі Бергоньє. Бандуристи виступили з великою програмою, до якої входили «Козацький похід», пісня про Морозенка, пісня «Літав орел», «Дума про смерть бандурника» і тринадцять народних історичних та побутових пісень.

У 1919 році більшовики входять до Києва, і В. Ємець емігрує за кордон, де дає концерти в містах Чехословаччини і Німеччини. 31922 року він веде школу гри на бандурі в Празі, в якій навчалися близько півсотні учнів. Серед них були і студенти, і професори, i науковці. У 1934 році Ємець переселився до Франції і продовжив концертну діяльність, брав участь у концертах французьких музичних товариств, влаштованих «Федерацією французьких артистів». Особливим був виступ у Ніцці на Французькій Рів'єрі 1934 року, що відбувся на великому концерті, на якому було 5000 глядачів з багатьох країн світу. Час від часу Василь Ємець відвідував Америку, а в 1936 році переїхав туди на постійне проживання. Відразу ж розпочинає свій перший концертний сезон з Канади, під час якого відвідує міста Монреаль, Торонто, Гамільтон, Лондон, Вінніпег, Саскатун, Ріджайна, Едмонтон, Калгарі, Ванкувер і багато фермерських поселень.

У січні 1937 року у залі Інституту просвіти міста Вінніпег було відсвятковано 25-ліття кобзарської діяльності Василя Ємця. Після Канади бандурист гастролював по США і давав багато концертів по всіх великих містах. На вдосконаленій бандурі грав класичну музику, власні інструментальні твори. 30 серпня 1938 року він одружується 3 дочкою підприємця Іллі Готри з Міннеаполісу Марією. Трохи згодом вони оселяються в Голівуді. Там В. Ємець займається виробництвом бандур, пише композиції і статті.

Протягом тривалого мистецького життя за межами України до науково-публіцистичного доробку митець долучив ще й чудовий професійний бандурний репертуар, основу якого склали перекладені твори та оригінальні авторські п’єси для бандури. Основною його 
музичною працею є композиція-поема «В горах України», створена на мелодії гуцульського танцю «Аркан» $з$ додатками деяких мотивів пісні «Вівчар на сопілці тужно виграває», коломийкових забарвлень, а також мотивів козацьких дум. Серед оригінальних творів бандуриста вирізняються «Передзвони», музична фантазія «Над Дніпром», «Із Карпатських гір», варіації «Подих української ночі» на пісню «Ніч яка, Господи», «Дощик», «Сніговій», п’єси «Гомін з України», «Танцюючі сніжинки», «Аркан», вокальні твори патріотичного змісту «Козак Шарівка», «Про Крути» та інші, що мають яскраве національне забарвлення.

Василь Ємець є автором кількох десятків статей на тему бандури, написаних українською, чеською, французькою та англійською мовами; праці «Кобза і кобзарі» (Берлін, 1922), «Кобза-бандура» («Дніпро», Чикаго, 15 травня, 1926), «Відродження кобзи» («Тризуб», Париж, 16 січня 1927), «До історії відродження новітнього кобзарства», «Наша держава», 14 січня 1954), «До мартирологів кобзарства» («Календар Свободи», Джерсі Сіті, 1956) та ін. Крім того, В. Ємець розробив та видав у Торонто (Канада) підручник для самостійного виготовлення бандур «Добре діло». Науково-публіцистична робота В. Ємця в еміграції мала велике значення, бо вона виконувала важливу просвітницьку місію серед світової спільноти, знайомлячи громадськість як Америки, так і Європи з багатою українською культурою через сприйняття одного із її провідних пластів - кобзарського мистецтва.

Теоретична праця «Кобза та кобзарі» була написана в 1923 році і видана в Берліні видавництвом «Українське слово». Книга розповідає про походження й побутування українського національного інструмента - кобзи, про життя відомих кобзарів старих часів, про кобзарські братства та їх діяльність, а також про відродження й удосконалення кобзи. Праця складається з передмови та шести глав, в кінці додається список літератури про кобзарські думи й кобзарів.

В передмові автор відзначає особливості географічного положення України, роль різних культурних впливів багатьох народів і племен, які побували на українській землі, здібність українського народу використати їх і пристосувати до себе, окреслює характерні відмінності російської та української музики, говорить про самобутність національного інструмента - кобзи.

Перша глава має назву «кілька слів про український національний інструмент та його походження». В ній автор подає будову кобзи та назви ії̈ частин, стрій, спосіб гри, а також висвітлює всі відомі версії 
походження бандури, деякі з них піддає сумнівам, говорить про значення інструмента для народу.

Друга глава «Кобзарські співи» розповідає про природу виконання дум та пісень, які були у репертуарі кобзарів. Тут автор говорить про неповторність виконання як в різних регіонах, у різних співців, так і в одного виконавця в різні дні.

В третій главі «Кобзарі старих часів» автор подає згадки про кобзарів з найдавніших часів - у «Слові о полку Ігоревім», в київському літописі XII століття, зображення на фресках київського собору св. Софії, говорить про популярність кобзи в козацькі часи, про розквіт кобзи в XVII-XVIII ст., про кобзарів та кобзарські капели при дворах російських царів та польських королів, подає указ Анни Іванівни 1738 року про відкриття Глухівської музичної школи, де навчали також і грі на бандурі, говорить про славу і гоніння кобзарів.

Четверта глава «Сліпі кобзарі й відродження кобзи» розповідає про долю кобзи після знищення Запорізької Січі, про те, як кобза стала інструментом не вільного козака, а убогих калік, описує творчість та життєвий шлях відомих сліпих кобзарів, приділяє багато уваги постаті Остапа Вересая, відзначає його надзвичайний емоційний вплив на слухачів. В главі окреслюється творчість кобзарів, які виступили на 12 археологічному з'їзді в Харкові у 1902 році, подвижницьку діяльність відомих митців, які зберегли для нащадків безцінний кобзарський репертуар та дбали про сліпих кобзарів. Автор говорить про відродження кобзи, концертування кобзарів у 1911-1912 рр. в Україні та за ії межами, створення в Києві першої кобзарської капели у 1918 році.

П'ята глава «Кобзарські братства» містить розповідь про братства, їх устрій, ритуали та мову. Тут автор цитує опис одного з братств, поданий в статті професора Сперанського, яка в перекладі на українську мову була вміщена в книзі Д. Ревуцького «Українські думи та пісні історичні».

В шостій главі «3 життя українських бардів» - автор розповідає про складне життя кобзарів в кінці XVIII - на початку XIX століття, про їх злидні та гоніння.

Василь Смець увійшов до плеяди видатних представників кобзарського мистецтва не лише своїми науковими публікаціями, високим виконавським рівнем, оригінальними та перекладеними творами для бандури, а також і пошуковою працею над вдосконаленням інструмента. Він прагнув створити бандуру, технічні можливості якої дозволили б легко виконувати твори, написані для фортепіано. 
Протягом восьми років тривала експериментаторська робота, що завершилася виготовленням інструмента 314 басовими струнами і 36 приструнками. На ньому В. Ємець 1946 року виконав першу частину (Adagio) «Місячної сонати» Л. Бетховена, викликавши щире захоплення і подив слухацької аудиторії технічними можливостями своєрідного дуету.

Випробувавши можливості цієї бандури завдяки виконанню класичного репертуару, В. Ємець продовжив удосконалення інструмента, поступово прилаштовуючи додаткові струни. На останній виготовленій ним бандурі харківського типу (1952 рік), що мала 62 струни, розміщені за хроматизмом, він припинив експерименти. Таке значне розширення бандурного звукоряду в поєднанні з рівноправною грою обох рук дало можливість В. Ємцю перекладати і виконувати твори Л. Бетховена, Ф. Ліста, А. Дворжака, П. Чайковського та ін.

Таким чином, завдяки першим підручникам Василя Емця та Зіновія Штокалка маємо гарне підгрунтя для удосконалення наукової літератури, написання нових шкіл гри на бандурі з висвітленням нових фахових завдань, удосконалення прийомів, способів звуковидобування на бандурі, удосконалення конструкції інструмента. А популяризації бандурного мистецтва через поєднання в репертуарі не тільки творів світової музичної класики та традиційного автентичного, українського репертуару, значно розширили виконавські межі інструмента. І тим самим створили не лише сприятливі умови для виступів з бандурою по цілому світу, а й підготували підгрунтя для розвитку традиційного українського народного мистецтва в нетрадиційних для нього умовах.

\section{СПИСОК ЛІТЕРАТУРИ}

1. Дутчак В. Кобзарський підручник Зиновія Штокалка: теоретичні та практичні узагальнення. Бандура. 2000. № 71-72. С. 21-23.

2. Ємець В. Кобза і кобзарі. Б.: Українське слово, 1923. 111 с.

3. Жеплинський Б. Кобзарськими стежинами. URL: http://www.ukrlit. vn.ua/article/1232.html

4. Литвин М. Струни золотії. К.: Веселка, 1994. 117 с.

5. Майстренко Л. Зіновій Штокалко - бандурист віртуоз. Бандура. НьюЙорк, 1981. № 3-4. С. 2-7.

6. Мішалов В. Зіновій Штокалко. Бандура. Нью-Йорк, 1981. № 3-4. C. $15-21$.

7. Shtokalko Z. Kobzars'ky pidruchnyk / Canadian Institute of Ukrainian Studies Press 352. Athabasca Hall University of Alberta. Edmonton, Alberta, Canada, 2001. 


\section{REFERENCES}

1. Dutchak V. (2000) Kobzarsjkyj pidruchnyk Zynovija Shtokalka: teoretychni ta praktychni uzaghaljnennja. Bandura№ 71-72. S. 21-23 [in Ukrainian].

2. Jemecj V. (1923) Kobza i kobzari. 1-she vyd. B.: Ukrajinsjke slovo [in Ukrainian].

3. Zheplynsjkyj B/ Kobzarsjkymy Stezhynamy URL: http://www.ukrlit.vn.ua/ article/1232.html

4. Lytvyn M. (1994) Struny zolotiji «Veselka», K. [in Ukrainian].

5. Majstrenko L. (1981) Zinovij Shtokalko - banduryst virtuoz. Bandura (NjjuJork). № 3-4. S. 2-7 [in Ukrainian].

6. Mishalov V. (1981) Zinovij Shtokalko.Bandura (Njju-Jork). № 3-4. S. 15-21 [in Ukrainian].

7. Shtokalko, Z. Kobzars'ky pidruchnyk.Canadian Institute of Ukrainian Studies Press 352. Athabasca Hall University of Alberta, Edmonton, Alberta, Canada [in English].

Стаття надійщла до редакції 29.11.2017

УДК 7.071.2.03:78.087.68](477)«185»Є. Вахняк

DOI 10.31723/2524-0447-2018-26-266-282

Чучман Василь Мар'янович

https://orcid.org/0000-0001-5076-7427

асистент кафедри музикознавства та хорового мистецтва факультету культури і мистецтв Львівського національного

університету імені Івана Франка

vassylch@yahoo.com

\section{ДИРИГЕНТСЬКА ШКОЛА ЕВГЕНА ВАХНЯКА НА ТЛІ ХОРОВОЇ КУЛЬТУРИ УКРАЇНИ}

Мета дослідження - проаналізувати функціонування диригентської школи Євгена Вахняка в контексті хорової культури України другої половини XX століття. Методологія дослідження передбачає застосування історико-генетичного, аналітичного, компаративного, музикознавчого, психологічно-типологічного та культурологічного методів. Зазначений методологічний підхід дозволяє здійснити комплексний аналіз змісту, форм, методів, иілей і результатів творчості Є. Вахняка, виявити низку суб'єктивних (індивідуальних особистісних рис) та об'єктивних (регіональних та загальнонаціональних традицій, тенденцій епохи) факторів, що стали визначальними у формуванні виконавських, педагогічних, методичних, репертуарних функціональних компонентів його диригентської школи. Наукова новизна полягає у тому, що вперше в

(C) Чучман В. М., 2018 